Pavlova Alina, $\mathrm{PhD}$ in Economics, assistant. Kyiv National University of Trade and Economics ORCID: 0000-0003-1660-5090

Kyiv, Ukraine

\title{
MARKETING STRATEGY FOR HOTEL ENTERPRISES AS A CORE TO BUSINESS DEVELOPMENT
}

The article analyzes the urgency of the development of the hotel industry in Ukraine as the nucleus of business development. The importance of the marketing strategy for the hotel industry is highlighted. The stages of marketing strategy of hotel enterprises are considered. The core of the business for the hotel industry has been identified.

Keywords: hotel enterprises, strategy, marketing strategy, core of business.

Павлова Аліна. Маркетингова стратегія підприємств готельного господарства як ядро розвитку бізнесу.

Проаналізовано актуальність розвитку готельного господарства в Украӥні як ядро розвитку бізнесу. Визначено важливість маркетингової стратегії для готельного господарства. Розглянуто етапи маркетингової стратегії готельних підприємств. Визначено ядро бізнесу для готельного господарства.

Ключові слова: готельні підприсмства, стратегія, маркетингова стратегія, ядро бізнесу.

Relevance of research topic. Nowadays, in the perspective of business development of different directions and industries, it is necessary to differ and have good tactics among competitors. The rapid development of technology, growing consumer demands, increased competition at the global level, over-regulation of the economy, profound social change - all open up wide opportunities and prospects in various fields of economic activity, in particular in the hotel industry.

Formulation of the problem. When economic change is ongoing, an enterprise in a market environment must: firstly, meet the requirements of buyers to compete successfully, and secondly, to adapt or anticipate change. They were identified by I. Ansoff [1], when he considered different levels of turbulence of the environment and classified the corresponding necessary reactions of the enterprise. According to him, today most companies are forced not only to adapt to changes in the environment, but 
also to develop a strategy for their anticipation. It is important for the company to choose the direction of strategic development and strategy. The problem of development and implementation of enterprise development strategy is receiving increasing attention in modern economic science. An important issue is the professional and effective provision of the company with effective marketing tools, which requires management to pay attention to the formulation of marketing strategies for their effective use. Strategy development should be consistent with its feasibility.

Analysis of recent researches and publications. Problems of change management and various aspects of the mechanism of enterprise development were devoted to the work of well-known domestic scientists: S. Nekrasov, N. Fedorov, M. Bidnyak, E. Panina, F. Khmil, M. Boyko, the study of strategic management and marketing, the formation of competitive marketing strategies, some of their elements and aspects are devoted to the work of many scientists: I. Ansoffa, K. Lindi, M. Martynenko, S.Filippova, O. Kuzmin, O.Melnyk, O. Mogilevskaya, P. Doyle, L. Shemaeva, O. Aref ' Eve, V. Grinyova, J. Lambena, B. Karloff, H. Koboyashi, F. Kotler, P. Doyle, I. Kretova, D. Crombrugge, S. Majaro, J. MacArthur, M. Mescon, N. Moiseeva, D. Aucker, A. Romanova, H. Takeuchi, T. Fujimoto, G. Shmalen, J. Day, Yu. Yudanova, D. Jobber, M. McDonald, E. Golubkov, P. Drucker, A. Porshnev, R. Fatkhutdinov and others. In scientific writings of foreign economists, the scientific approach to the construction of the enterprise marketing strategy based on the definition of business, focusing on its constituent elements, has become more relevant recently. This approach proves effective in practice. In the Ukrainian economic literature, the term «key of business» is practically not used. At the present stage of development of domestic marketing, it is not enough in the sphere of the restaurant industry to research the marketing strategies of enterprises, considering the potential of their business, so the chosen topic of research is relevant.

Presenting main material. The development of the hotel business is ensured primarily by the formation of its overall strategy. Marketing strategy plays an important role in the effective implementation of corporate enterprise strategy. The place of marketing strategy in the strategic planning system is shown in pic. 1.

When developing a marketing strategy in the hospitality industry, it is very important to define the business of the enterprise. First, for all this definition reveals the very essence of the enterprise, that is, its main purpose. Therefore, the definition of business can be considered as a statement of the mission of the company. Second, defining the business of an enterprise sets the boundaries for its efforts and sets the horizons for further development, that is, it forms the field of activity in which the enterprise will compete. Defining an enterprise's business is also the starting point for developing a marketing strategy. Changes in the definition of activities can cause major changes in strategic direction, sources of revenue, priorities in the allocation of 
resources, performance indicators that need to be monitored (Dyukov I.I., 2008, p. 124).
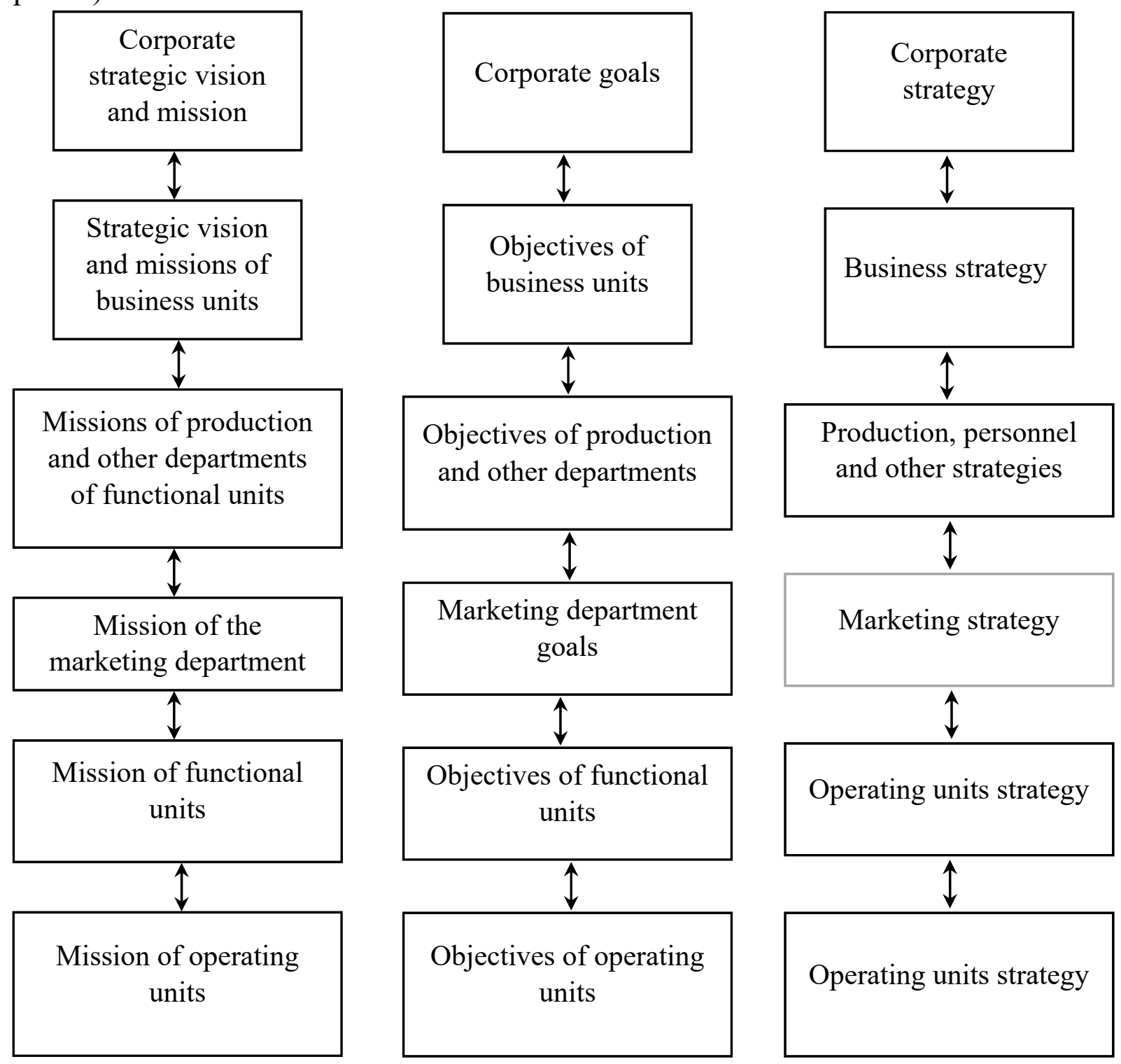

Picture 1. Marketing vision, mission, goals and strategy in the hierarchical structure of corporate governance

Correct definition helps the company to move away from being focused on internal problems, thus enhancing the characteristics of the products or services offered, and makes it clearer to show what the business offers to its customers. The structure of business definition can be represented as a set of these four elements (Day J., 2015, 3 p. 11).

The first element is consumer inquiries, which are at the forefront of defining a business because consumers meet their needs or solve their problems, trying to find not just products or services, but collections of benefits. The way consumers plan to use a product or service determines the type of benefits they seek. To give them these benefits, manufacturers are trying to offer consumers complete functional packages 
that include additional services. This practice leads to the emergence of a whole group of questions that help more clearly determine what and how the company intends to compete with rivals. To create the most profitable consumer demand, you need to start with a deep study of consumer attitudes, behavior and economics. It is important to understand, at the most elementary level, which consumers are profitable to serve and who are not, and to modify the company's products and services as efficiently as possible so that more targeted consumers can be profitably served, giving them the highest value (no more and no less). This systematic approach is called Understanding Attitude, Behavior and Economics, or «Three-Dimensional Consumer Look».

The second element of defining a business is to distinguish consumer segments. The consumer segment is a group of consumers with similar needs and general characteristics, meaning that they are strategically comparable to each other. The business can choose the option when it will serve all potential consumers, or focus on a separate segment, selected from the broad market. One of the hardest choices is geography. Many businesses, because of resource constraints or high transportation costs, or the condition that their products soon deteriorate, limit themselves only to regional or national markets. Other restrictions related to the tendency to a particular geographical area are tariffs and other economic barriers encountered in international trade.

The third element to defining a business is technology and materials. Technology describes the way in which a customer's needs can be met or a function performed. The end product is essentially a sequence of technology use. Often, the general need of restaurant industry consumers can only be met with the help of several technologies of production and storage (pressure frying, shock cooling and freezing, vacuum packing). Depending on the difficult market conditions, different options may be cheaper.

The fourth element in the business definition structure is the value chain activities. This direction addresses the question of how close it is to the end consumer or, conversely, to the raw materials and components of the organization to locate their business; how to access the market (through which communication and distribution channels) and whether to own or use the services of intermediaries.

The marketing strategy of a hotel business depends both on the definition of the business and, to a large extent, on its core, serving as a set of services, products, customers, equipment, personnel, capabilities, resources, competencies, brand, service standards and service methods that provide a stable and profitable growth. The core of an enterprise's business is potentially the most profitable, privileged customers, the most important products and services, as well as the most important strategic and unique resources. It is advisable to investigate exactly how the elements of the definition of business and its core relate to elements of the overall concept of the restaurant business (pic. 2). 


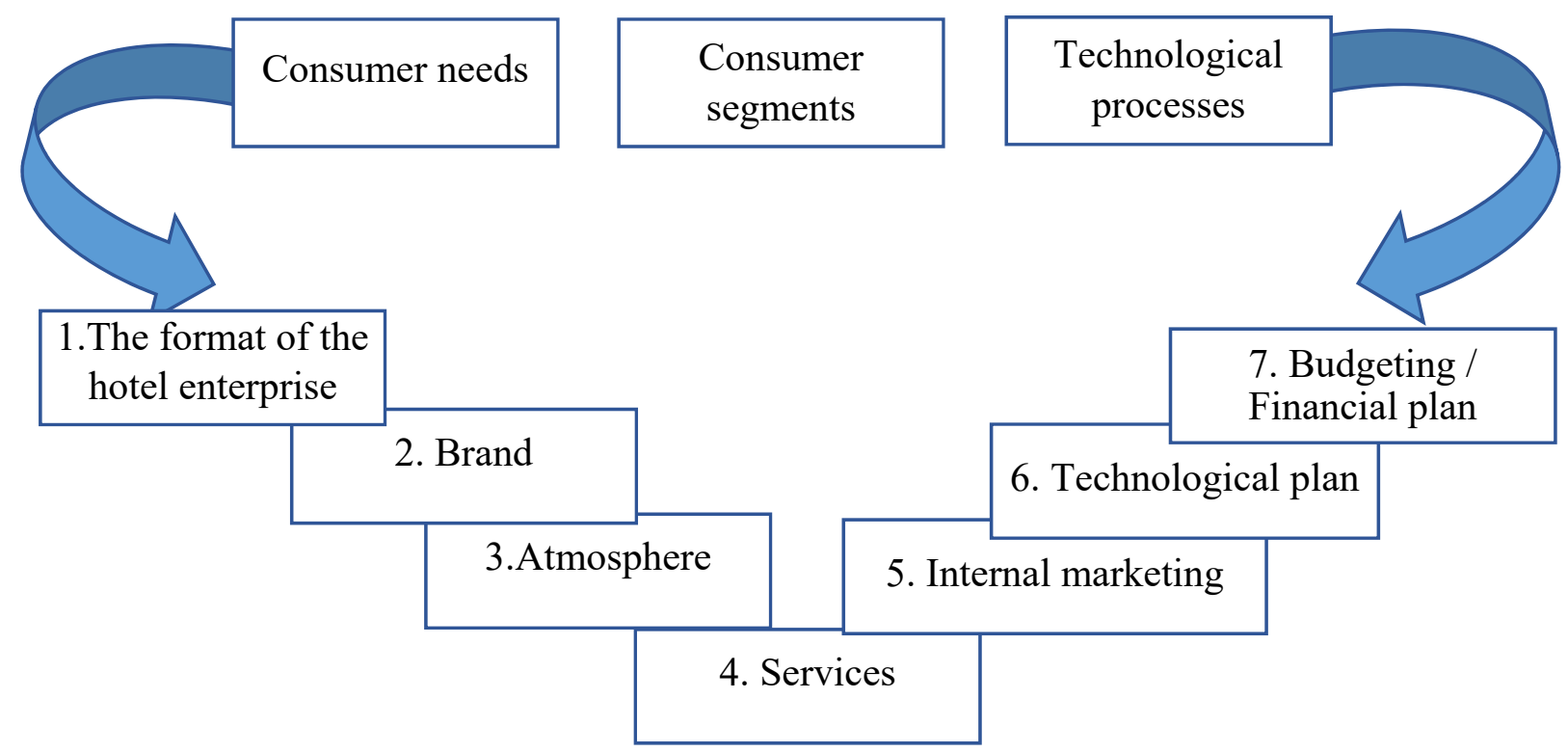

Picture 2-Relationship between business definition elements and elements of the overall concept of a hotel business

Picture 2 shows that:

- the hospitality industry is determined according to consumer needs and segments, considering the technology to be used;

- the brand of the hotel enterprise is formed on the basis of consumer preferences;

- the atmosphere of the company is designed to attract the desired consumer segment, considering its needs;

- the range of services provided by the hotel enterprise is formed on the basis of needs, considering the consumer segment in terms of income and consumer preferences;

- internal marketing should create the marketing features of a particular restaurant establishment, such as non-standard ordering or menu design;

- technological plan is shaping the technologies that will be used in a separate hotel enterprise;

- budgeting / financial plan provide budgeting models, cash flows and economic evaluation of the performance of the hotel business.

When developing a marketing strategy should determine the areas of activity of the company. Each activity can be associated with one product as well as a group of similar products (or services). However, the key of the marketing strategy should be the core of the business as what determines the most profitable aspects of the hotel business (Lamben J.-J., 2004, p. 548).

In order to define marketing strategies in a hotel business, you need to identify those measures that are an integral part of marketing in this area and related to the parameters of the hotel business core. These measures include:

- identification of client's wishes and needs; 
- creation of a complex of goods and services of marketing-mix) that would satisfy these desires and needs;

- promotion of goods and services on the market (promotion) and their sale in order to create a level of profitability of the enterprise and correspond to the interests of shareholders.

The first and foremost task of marketing is to understand the most profitable consumers and be sure to study their desires and needs. Another important direction in harnessing the potential of the core business is to use marketing tools to create the most profitable products and services for subsequent offering to customers. The next elements of marketing that are influenced by the core of the business are the most important channels for promoting goods and services in the marketplace, advertising and marketing, created products and services. The final piece of marketing for using the core of business is to generate a reasonable level of revenue in the value chain of the hotel business as defined (Chris Z., James A., 2016, p. 156).

The formed core of the hotel business solves many issues that are decisive in the formulation of a marketing strategy, namely whether the core is determined, whether it should be modified, whether the core potential is fully utilized. The answers to these questions form the basis of a marketing decision support system for developing the following stages of a marketing strategy (Pyatnitskaya G.T., 214, p. 231):

- development of goals by elements of the marketing complex based on the previously set goals

- highlight the segments that are most interesting for the company to which they will focus. The main purpose of segmentation is to focus them on specific segments, since it is not possible to meet the needs of all consumers of hotel services at the same time;

- analysis of the commodity policy of a given catering company: assortment analysis ( $\mathrm{ABC}$ - analysis); comparison of the range with the main competitors; identifying the directions of development in accordance with the set goals, analysis of the raw material situation;

- price policy analysis: determination of production and sales costs; comparison with the prices of the main direct competitors; determining the pricing strategy according to the purpose;

- service delivery: analysis of service quality; personnel analysis; evaluation of the hotel's image; development or improvement of the standard of service;

- communication policy analysis: evaluation of the effectiveness of previous advertising campaigns or promotions; development of a new advertising campaign and calculation of the promotion budget in accordance with the set goal;

- conducting a SWOT analysis of the company, considering all the previous steps; comparison of the data of the analysis of our enterprise with the analysis of the main competitors; identifying promising competitive advantages and developing a company positioning strategy. 
The effectiveness of the chosen marketing strategy is verified through a system of special indicators that can be divided into two groups: the criteria of economic efficiency and the criteria of social efficiency. The first group of criteria includes indicators of resource efficiency, enterprise performance and competitive position. Social performance criteria evaluate the quality of production activity, the quality of service. This metric system has analytical capabilities and provides diagnostics of the current state of the enterprise, which serves as a basis for making marketing decisions aimed at increasing efficiency.

Conclusion. Summarizing the above, we note:

1. Formulated marketing mission, goals and functional strategy in the hierarchical structure of the corporation.

2. The main elements that determine a business are consumer inquiries, consumer segments, technologies and materials and the place in the value chain.

3. The core of the hotel business enterprise is identified, which allows to solve many problems in forming the marketing strategy of the hotel enterprise (in particular, such as: Does a certain core have force? Should it be changed? Is the potential of the $\mathrm{c}$ fully utilized?).

4. The marketing strategy of a hotel enterprise as a component of strategic planning should be based on the core of the business, as it identifies the most profitable and promising elements of the enterprise's economic activity and allows it to form effective directions of development.

5. Further areas of research in the strategic marketing of hotel businesses should be scientific developments on the conceptual foundations of the formation of marketing strategies based on the core of the business.

\section{REFERENCES}

1. Craven David V. Strategic Marketing, 2012. 752 p.

2. Chris Z., James A. Company growth strategy in the era of instability, 2016. $192 \mathrm{p}$.

3. Day J. Strategic marketing / J. Day. - M.: Eksmo, 2015. 640 p.

4. Lamben J.-J. Market oriented management. Strategic and operational, 2004. $800 \mathrm{p}$.

5. Pyatnitskaya G.T. Restaurant management Ukraine: Market Transformations, Innovative Development, Structural Reorientation: A Monograph / G.T. Pyatnytska. Issue of the Kiev National University of Trade and Economics, 2014. 465 p. 